\title{
Grain quality assessmentof direct seeded basmati rice (Oryza sativa L.) under different irrigation regimes in Indian Punjab
}

\author{
Jagmohan Kaur ${ }^{1 *}$, S. S. Mahal ${ }^{1}$ and Amarjeet Kaur ${ }^{2}$ \\ ${ }^{1}$ Department of Agronomy, Punjab Agricultural University, Ludhiana -141004 (Punjab), INDIA \\ ${ }^{2}$ Department of Food Science and Technology, Punjab Agricultural University, Ludhiana -141004 (Punjab), INDIA \\ *Corresponding author. E-mail: jagmohanpau3@gmail.com \\ Received: June 12, 2016; Revised received: January 30, 2017; Accepted: April 4, 2017
}

\begin{abstract}
Irrigation water, being a scarce resource, requires proper management for good quality aerobic basmati rice production. Field experiments were conducted at Punjab Agricultural University, Ludhiana to evaluate the effect of different irrigation schedules on grain quality of direct seeded basmati rice 'Pusa Basmati 1121'. Ten treatments comprising of conventional puddled transplanting and nine in direct seeding were tested in randomized block design with four replications. Direct seeding treatments comprised of combination of withholding first irrigation for 6,9 or 12 days after sowing and follow up irrigations at 30,50 or $70 \mathrm{~mm}$ cummulative pan evaporation (CPE). The milling quality characters of rice like brown, milled and head rice recoveries were highest in conventional transplanting (81.4, 70.9 and $52.4 \%$, respectively) statistically at par with irrigation schedule of withholding first irrigation for 6 days and subsequent irrigations at $30 \mathrm{~mm} \mathrm{CPE} \mathrm{(80.3,} 69.9$ and $51.1 \%$,respectively) significantly better than rest of the treatments. The other quality characters like protein content, minimum cooking time, elongation ratio etc. were also significantly affected by different irrigation schedules at $5 \%$ level of significance. The maximum values of protein content $(7.26 \%)$ and minimum cooking time $(23.5$ minutes) were obtained in irrigation schedule of withholding first irrigation for 6 days and subsequent irrigations at $30 \mathrm{~mm}$ CPE whereas elongation ratio was maximum in conventional transplanting (1.87). In Indian Punjab, good quality direct seeded basmati rice can be obtained by holding the first irrigation for 6 days and then irrigating at $30 \mathrm{~mm}$ CPE with yields comparable to transplanted rice.
\end{abstract}

Keywords: Aerobic rice, Cooking quality, Hectolitre weight, Milling and transplanted rice

\section{INTRODUCTION}

Globally, rice (Oryza sativa L.) is the principal cereal crop responsible for feeding half of the population and is a major source of livelihood of the rural population of tropical and subtropical areas of Asia, Africa and Latin America. More than 90 per cent of the world's rice is grown and consumed in Asia alone (Kumar and Ladha, 2011). Presently, basmati rice is gaining more importance due to its unique eating and cooking qualities and has premium value in national and international markets, fetching 2-3 times more price than other coarse rice grains. In Indian Punjab, remunerative crop like basmati rice offers a lot of scope for crop diversification.

For substantial reduction in irrigation water use, rice is an important target as the water consumption for rice production is much higher than for other cereal crops (Tuong and Bouman, 2003), due to its lower water use efficiency. The global water footprint of rice production is 784 billion $\mathrm{m}^{3}$ year $^{-1}$ with an average of $1325 \mathrm{~m}^{3} \mathrm{t}^{-1}$, whereas in India it is 255.5 billion $\mathrm{m}^{3}$ year $^{-1}$ with an average of $2020 \mathrm{~m}^{3} \mathrm{t}^{-1}$ (Chapagain and Hoekstra,2011). Also, the per capita availability of water used in agriculture is declining because of urbanization and industrialization. In the present scenario of dominance of rice-wheat system in Indogangetic plains of North-West India (NW-IGP) and further cultivation of puddled transplanted rice in coarse textured soils, the water table is going down at an alarming rate (Mahajan et. al., 2012). The emerging water crisis and further water-guzzling nature of transplanted rice are driving the search for alternative rice establishment methods to enhance the water productivity. Among different water-saving novel rice production systems, direct seeding rice culture, an emerging production system in the NW-IGP can help to make irrigated rice cultivation more sustainable and profitable than conventional transplanting mainly by improving labour and water productivity (Kumar and Ladha, 2011). Extensive studies are being conducted for the fine tuning of production technologies of direct seeding to improve the yield as well as quality of rice. The information on irrigation schedules for direct seeded basmati rice with respect to its quality is still lacking. The modification in irrigation schedules leads to change in different soil properties i.e. physical, chemical and biological, which in turn leads to change 
in nutrient availability. Moreover, water being a universal solvent, plays important role for nutrient uptake by the roots by interception, mass flow and diffussion. Mass flow of soil water to supply the transpiration stream transports most of the nitrate to roots, thus moisture availability affects nutrient availability. The changed nutrient availability can influence the nutrient uptake which in turn affects the quality of rice which is of great concern to the consumers (Sandhu et al., 2014).

Rice grain quality is influenced dramatically by water status in the soil (Michael et al., 1996) especially during the grain filling period (Pandey et al., 2014). Grain filling pattern has marked influence on final grain quality (Xie et al., 2001); which may be due to the differential filling rates and assimilate competition (Zhang et al., 2002). Since the grain development conditions are different under puddled tranplanted and aerobic system, thus, grain quality characteristics are differently affected. Moreover, moisture stress affects rice growth and reduces grain yield and quality (Carlos et al., 2008). But, moderate water deficit during the grain filling stage enhances grain filling rate leading to an increase in the number of grains and ultimately yield (Yang et al., 2001).

Therefore, it becomes imperative to find out appropriate irrigation management practice for enhancing the yield without impairing quality of DSBR and this study was thus undertaken with the objective to evaluate different irrigation schedules under direct-seeded conditions in terms of quality of DSBR in NW-IGP.

\section{MATERIALS AND METHODS}

Experimental site: The experiments were conducted at the research farm of Punjab Agricultural University, Ludhiana, Punjab, India (30 $56^{\prime} \mathrm{N}, 75^{\circ} 52^{\prime} \mathrm{E}, 247 \mathrm{~m}$ above sea level) during the summer seasons of 2011 and 2012. The site is characterized by sub-tropical and semi-arid type climate with a hot summer, wet monsoon season (July -September) and a cool dry winter. Average annual rainfall is $734 \mathrm{~mm}, 85$ per cent of which falls during the monsoon season (Mahajan et $a l ., 2011)$. The soil of the experimental field was loamy sand (Entisol,Typic Ustipsament) with normal soil reaction ( $\mathrm{pH}$ of 7.6) and electrical conductivity $(0.16$ $\left.\mathrm{dS} \mathrm{m}^{-1}\right)$, medium in organic carbon $(0.42 \%)$, available nitrogen $\left(280.27 \mathrm{~kg} \mathrm{ha}^{-1}\right)$, availablephosphorus $(21.65$ $\left.\mathrm{kg} \mathrm{ha}^{-1}\right)$ and available potassium $\left(210.29 \mathrm{~kg} \mathrm{ha}^{-1}\right)$. The site was under a rice-wheat cropping system for 3 years before the establishment of the experiment.

Experimental design and crop management: The experiment was laid out in four replications in a randomized complete block design using rice cultivar Pusa Basmati-1121 during the kharif seasons of 2011 and 2012. Ten treatment combinations were tested viz., Conventional puddled transplanting and 9 others of direct seeding with pre-seeding irrigation and are as follows:

\begin{tabular}{|c|c|}
\hline Treatments & Abbreviation used \\
\hline Conventional puddled transplanting & - \\
\hline $\begin{array}{l}\text { Hold first irrigation for } 6 \text { days }+ \\
\text { follow up irrigation at } 30 \mathrm{~mm} \mathrm{CPE}\end{array}$ & $\mathrm{I}_{6 \mathrm{DAS}+} 30 \mathrm{~mm} \mathrm{CPE}$ \\
\hline $\begin{array}{l}\text { Hold first irrigation for } 6 \text { days }+ \\
\text { follow up irrigation at } 50 \mathrm{~mm} \mathrm{CPE}\end{array}$ & $\mathrm{I}_{6 \mathrm{DAS}}+50 \mathrm{~mm}$ CPE \\
\hline $\begin{array}{l}\text { Hold first irrigation for } 6 \text { days } \\
+ \text { follow up irrigation at } 70 \mathrm{~mm} \mathrm{CPE}\end{array}$ & $\mathrm{I}_{6 \mathrm{DAS}+}+70 \mathrm{~mm} \mathrm{CPE}$ \\
\hline $\begin{array}{l}\text { Hold first irrigation for } 9 \text { days }+ \\
\text { follow up irrigation at } 30 \mathrm{~mm} \mathrm{CPE}\end{array}$ & $\mathrm{I}_{9 \mathrm{DAS}}+30 \mathrm{~mm}$ CPE \\
\hline $\begin{array}{l}\text { Hold first irrigation for } 9 \text { days }+ \\
\text { follow up irrigation at } 50 \mathrm{~mm} \mathrm{CPE}\end{array}$ & $\mathrm{I}_{9 \mathrm{DAS}+} 50 \mathrm{~mm} \mathrm{CPE}$ \\
\hline $\begin{array}{l}\text { Hold first irrigation for } 9 \text { days }+ \\
\text { follow up irrigation at } 70 \mathrm{~mm} \mathrm{CPE}\end{array}$ & $\mathrm{I}_{9 \mathrm{DAS}}+70 \mathrm{~mm} \mathrm{CPE}$ \\
\hline $\begin{array}{l}\text { Hold first irrigation for } 12 \text { days }+ \\
\text { follow up irrigation at } 30 \mathrm{~mm} \mathrm{CPE}\end{array}$ & $\mathrm{I}_{12 \mathrm{DAS}+30 \mathrm{~mm} \mathrm{CPE}}$ \\
\hline $\begin{array}{l}\text { Hold first irrigation for } 12 \text { days }+ \\
\text { follow up irrigation at } 50 \mathrm{~mm} \mathrm{CPE}\end{array}$ & $\mathrm{I}_{12 \mathrm{DAS}+}+50 \mathrm{~mm} \mathrm{CPE}$ \\
\hline $\begin{array}{l}\text { Hold first irrigation for } 12 \text { days }+ \\
\text { follow up irrigation at } 70 \mathrm{~mm} \mathrm{CPE}\end{array}$ & $\mathrm{I}_{12 \mathrm{DAS}+}+70 \mathrm{~mm} \mathrm{CPE}$ \\
\hline
\end{tabular}

Sowing of nursery as well as direct seeding was done on same days i.e. $24^{\text {th }}$ and $23^{\text {rd }}$ June during 2011 and 2012, respectively. In conventionally transplanted plots puddling was done manually and transplanting of 25 days old nursery was done at $20 \times 15 \mathrm{~cm}$, row to row and plant to plant spacing. Direct seeding of rice was done using a seed rate of $25 \mathrm{~kg} \mathrm{ha}^{-1}$. Seed was placed at a depth of $2.5 \mathrm{~cm}$ using single row drill with $20 \mathrm{~cm}$ row to row spacing. The gross and net plot size was 18 and $10 \mathrm{~m}^{2}$, respectively. Each plot was surrounded by a buffer of $0.75 \mathrm{~m}$ width.

In direct seeded treatments, nitrogen @ $40 \mathrm{~kg} \mathrm{ha}^{-1}$ in the form of urea was broadcasted in two equal splits on 3 and 6 weeks after sowing, whereas, the same dose was applied in transplanted treatments on 3 and 6 weeks after transplanting. The recommended dose of phosphorus $\left(\begin{array}{llllll}30 & \mathrm{~kg} & \mathrm{P}_{2} \mathrm{O}_{5} & \mathrm{ha}^{-1}\end{array}\right)$ as single super phosphate, potassium $\left(30 \mathrm{~kg} \mathrm{~K}_{2} \mathrm{O} \mathrm{ha}^{-1}\right)$ as muriate of potash and zinc sulphate heptahydrate $\left(62.5 \mathrm{~kg} \mathrm{ha}^{-1}\right)$ were applied at the time of seedbed preparation by broadcasting.

In conventional transplanting treatment, water was kept ponded during the first fifteen days. After fifteen days, these plots were irrigated two days after the ponded water infiltrated into the soil. The irrigation was skipped if sufficient rain was received. Irrigation application was stopped before fifteen days of harvest. In case of direct seeding pre-sowing irrigation was applied and after that irrigations were applied as per treatments. The depth of irrigation water applied was $75 \mathrm{~mm}$. The time required for the application of irrigation water was computed by using the following formula :

$\mathrm{ad}=\mathrm{Qt}$

Eq. 1 $\mathrm{t}=\mathrm{ad} / \mathrm{Q}$, where $\mathrm{a}$ is area $\left(\mathrm{m}^{2}\right), \mathrm{d}$ is depth of irrigation (m), $\mathrm{Q}$ is discharge per unit time $\left(\mathrm{m}^{3} / \mathrm{sec}\right)$ and $\mathrm{t}$ is time 


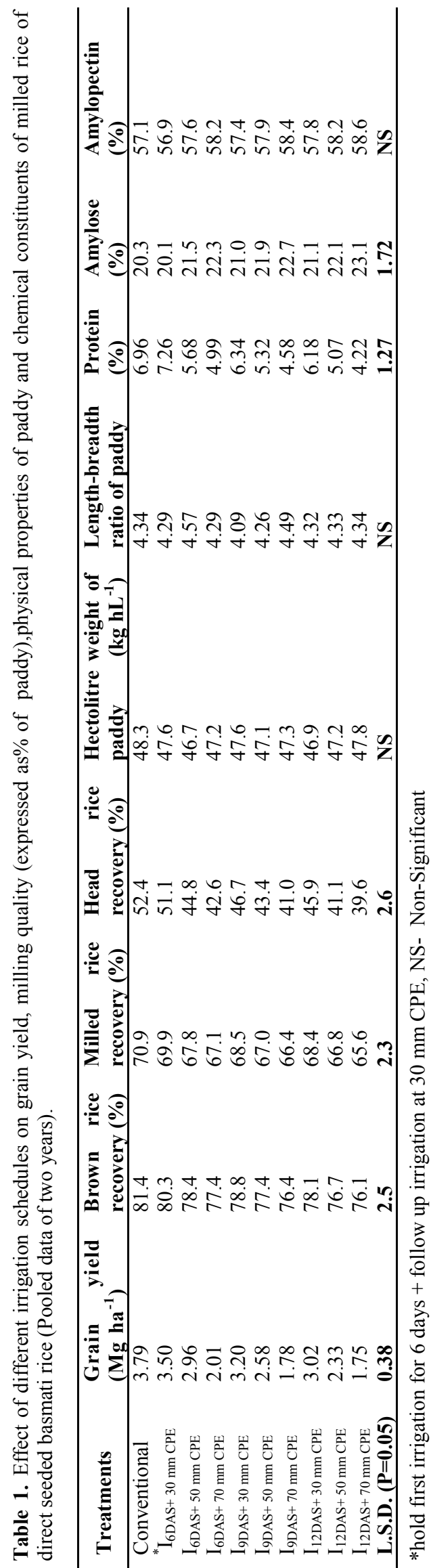

taken in seconds.

The discharge was measured using Parshall flume. The total rainfall received during the crop season was 963.2 $\mathrm{mm}$ (uneven as $400 \mathrm{~mm}$ received on a single day) and $387 \mathrm{~mm}$ during 2011 and 2012, respectively. At harvest, the grain yield was recorded and was expressed in $\mathrm{Mg} \mathrm{ha}^{-1}$ at 14 per cent moisture content using the following formula:

$$
\mathrm{Y}=\frac{\text { Net plot yield }(\mathrm{kg})}{\text { Net plot size }\left(\mathrm{m}^{2}\right)} \times 10 \times \frac{100-\mathrm{Mx}}{100-14}
$$

Where,

$\mathrm{Y}=$ Adjusted grain yield in $\mathrm{Mg} \mathrm{ha}^{-1}$ at 14 per cent moisture content

$\mathrm{Mx}=$ Moisture content of grains (per cent) at the time of recording yield in the field

Dehusking and milling: Weighed samples of clean paddy were dehusked in a Satake Rubber Roll Laboratory Sheller. Shelled (brown) rice was weighed and expressed as percentage of hulled/brown rice recovery. The shelled rice (brown rice) samples were milled (McGill miller No. 2). The time of polishing was adjusted to obtain a $6 \%$ degree of polish in all the samples. Milled rice was weighed and expressed as percentage of paddy. Rice grading device was used to separate broken kernels from the milled rice. The kernels with more than two-third length were considered as head rice. Head rice was weighed and expressed as percentage of paddy.

Physicochemical and cooking properties: The milled whole rice kernals were used for the evaluation of physicochemical and cooking properties. The hectolitre weight $\left(\mathrm{kg} \mathrm{hL}^{-1}\right)$ was determined by filling a container of one litre capacity and grains were made to fall in the container from an overhead storage hoper. The grains in container were leveled with the help of a scale. The weight of grains $(\mathrm{kg})$ was recorded in triplicate from every plot, average was determined and it was multiplied with 100 to convert it into hectolitre weight $\left(\mathrm{kg} \mathrm{hL}^{-1}\right)$. The length and breadth of ten grains were measured before and after cooking of samples and grain length- breadth ratio was calculated as follows:

$\mathrm{L} / \mathrm{B}=$ Average of length of 10 grains $(\mathrm{mm}) /$ Average of breadth of 10 grains $(\mathrm{mm})$

(Equation 3)

Protein and Amylose content of milled rice was determined with Zx 800 Near Infrared Grain Analyzer of Zeltex Inc and the values were expressed as percentage on weight basis. Amylopectin content in grains were determined by the following formula given by Low (1994).

Amylopectin $(\%)=100-\{$ Moisture $(\%)+$ Protein $(\%)$ + Amylose (\%) + Ash (\%) $\}$ (Equation 4)

For determination of minimum cooking time, head rice were cooked in a test tube containing distilled water (1:10) in a boiling water bath. Few grains were 
Jagmohan Kaur et al. / J. Appl. \& Nat. Sci. 9 (2): 663 - 668 (2017)

Table 2. Effect of different irrigation schedules on cooking quality of milled direct seeded basmati rice (Pooled data of two years).

\begin{tabular}{|c|c|c|c|c|c|}
\hline Treatments & $\begin{array}{l}\text { Minimum cooking } \\
\text { time (minutes) }\end{array}$ & $\begin{array}{l}\text { Length -breadth ratio of } \\
\text { cooked milled rice }\end{array}$ & $\begin{array}{l}\text { Elongation } \\
\text { ratio }\end{array}$ & $\begin{array}{l}\text { Water uptake } \\
\text { ratio }\end{array}$ & $\begin{array}{l}\begin{array}{l}\text { Gruel solids } \\
\text { loss }(\%)\end{array} \\
\end{array}$ \\
\hline Conventional & 23.0 & 5.29 & 1.87 & 3.24 & 2.99 \\
\hline${ }^{*} \mathrm{I}_{6 \mathrm{DAS}}+30 \mathrm{~mm} \mathrm{CPE}$ & 23.5 & 5.22 & 1.85 & 3.16 & 2.96 \\
\hline $\mathrm{I}_{6 \mathrm{DAS}}+50 \mathrm{~mm} \mathrm{CPE}$ & 21.9 & 5.43 & 1.80 & 3.05 & 3.32 \\
\hline $\mathrm{I}_{6 \mathrm{DAS}}+70 \mathrm{~mm} \mathrm{CPE}$ & 20.4 & 5.51 & 1.79 & 2.98 & 3.60 \\
\hline $\mathrm{I}_{9 \mathrm{DAS}}+30 \mathrm{~mm} \mathrm{CPE}$ & 22.6 & 5.26 & 1.83 & 3.17 & 3.19 \\
\hline $\mathrm{I}_{9 \mathrm{DAS}+}+50 \mathrm{~mm} \mathrm{CPE}$ & 21.0 & 5.57 & 1.79 & 3.03 & 3.40 \\
\hline $\mathrm{I}_{9 \mathrm{DAS}}+70 \mathrm{~mm} \mathrm{CPE}$ & 19.8 & 5.61 & 1.77 & 2.94 & 3.77 \\
\hline $\mathrm{I}_{12 \mathrm{DAS}}+30 \mathrm{~mm} \mathrm{CPE}$ & 22.1 & 5.28 & 1.83 & 3.05 & 3.22 \\
\hline $\mathrm{I}_{12 \mathrm{DAS}+}+50 \mathrm{~mm}$ CPE & 20.6 & 5.58 & 1.79 & 2.90 & 3.54 \\
\hline $\mathrm{I}_{12 \mathrm{DAS}+} 70 \mathrm{~mm}$ CPE & 19.4 & 5.63 & 1.76 & 2.86 & 3.92 \\
\hline L.S.D. $(P=0.05)$ & 0.77 & NS & 0.04 & NS & 0.27 \\
\hline
\end{tabular}

NS- Non-Significant

collected after $5 \mathrm{~min}$ and thereafter, 1 min interval during the cooking operation to determine the extent of cooking by pressing between two glass slides. Cooking time was recorded as the time taken until the disappearance of white core in more than $95 \%$ of the collected grains. The sample was drained and rinsed with distilled water on a Buchner funnel, allowed to drain for $2 \mathrm{~min}$ and the total volume of the gruel was measured. The gruel was transferred to a hot air oven maintained at $105 \pm 2{ }^{\circ} \mathrm{C}$ in a tarred petri dish and dried to constant weight. Weight of dried material was recorded as gruel solids loss (\%). The grains were placed between filter papers to remove excess water and weighed. Water uptake was calculated as the ratio of weight of cooked grains to the weight of uncooked grains. Elongation ratio was determined by dividing cumulative length of ten cooked kernels by length of ten uncooked kernels.

Statistical analysis: The data was subjected to analysis of variance (ANOVA) as suggested by Cochran and Cox (1967) and the treatment means were compared at $5 \%$ level of probability.

\section{RESULTS AND DISCUSSION}

Grain yield: The highest grain yield was accrued in conventional transplanting $\left(3.79 \mathrm{Mg} \mathrm{ha}^{-1}\right)$ which was statistically at par with direct seeded basmati rice (3.50 $\mathrm{Mg} \mathrm{ha}{ }^{-1}$ ) where water was withheld for 6 days after sowing and subsequent irrigations were applied at 30 $\mathrm{mm}$ CPE $\left(\mathrm{I}_{6 \mathrm{DAS}}+30 \mathrm{~mm} \mathrm{CPE}\right)$ and was significantly higher than all other irrigation schedules (Table 1). This was due to the improved growth as well as yield attributes due to the congenial edaphic conditions resulting from the frequent irrigations as water plays an important role in maintaining normal cell integrity, cell elongation, functioning of biopolymers apart from enhancing nutrient availability and translocation of photosynthates to grain (Singh,2004). The decrease in grain yield was due to the stress caused by decrease or delay in the frequency of irrigations. In similar studies conducted by Shekara et al. (2010), it was found that irrigation scheduled at IW/CPE ratio of 2.5 produced higher yield (equivalent to $30 \mathrm{~mm} \mathrm{CPE}$ ) as compared to IW/CPE ratio of 1.0 (equivalent to $70 \mathrm{~mm} \mathrm{CPE}$ ). Also,with the increase in the time span of first irrigation from 6 to 12 days, the water stress was observed and thus caused reduction in the grain yield.

\section{Quality characters of basmati rice}

Milling quality: Milling quality largely determines the price of rice in the market. Various milling quality characters of rice like brown, milled and head rice recovery of the treatments viz., conventional transplanting and $\mathrm{I}_{6 \mathrm{DAS}}+30 \mathrm{~mm}$ CPE were statistically at par and significantly better than rest of the treatments (Table 1). Although genotype plays an important role in determination of rice quality but environment also significantly interacts with genotype to determine the final quality (Chen and Zhu, 1999). Increase in the water stress reduced brown, milled and head rice recovery during both the years. These results are corroborated by the findings of Huang et al. (2008). They studied three irrigation regimes, i.e. well-watered (WW), moderate dry-wet alternate irrigation (MD: soil was re-watered when the soil water potential reached $20 \mathrm{kPa}$ ) and severe dry-wet alternate irrigation (SD: soil was re-watered when the soil water potential reached $-40 \mathrm{kPa}$ ), the treatments were imposed from 7 days after heading up to maturity and it was found that compared with WW, MD significantly increased, whereas SD significantly reduced, brown, milled and head rice recovery. Reduction in the water input reduced brown as well as head rice recovery was also reported by Cheng et al. (2003).

Physical properties of paddy: The hectolitre weight of paddy as well as length-breadth ratio of paddy were not influenced significantly by any of the irrigation schedules (Table 1).

Chemical constituents of milled rice: The irrigation schedules significantly influenced the protein as well the amylose content of the grains (Table1). Maximum protein content in milled rice was found in $\mathrm{I}_{6 \mathrm{DAS}}+30 \mathrm{~mm}$ CPE treatment $(7.26 \%)$ which was statistically at par 
with conventional transplanting $(6.96 \%), \mathrm{I}_{9 \mathrm{DAS}}+30 \mathrm{~mm}$ ${ }_{\mathrm{CPE}}(6.34 \%)$ and $\mathrm{I}_{12 \mathrm{DAS}+30 \mathrm{~mm} \mathrm{CPE}}(6.18 \%)$ treatments and showed significant reduction in rest of the treatments at $5 \%$ level of significance. The range of reduction varied from 7.26-4.22\%. Protein is one of the most important determinants of grain quality in rice. The increase in nitrogen content in grains is responsible for higher protein content and proteins provide hardness and make the grains resistant to breakage during milling (Cagampang et al., 1966). Frequent irrigations result in better translocation of nitrogen to grains. With the increase in the moisture stress, there is decrease in the protein content which might be due to the increased protease activity which induce breakdown of proteins (Agarwal et al., 1995). More the protease activity, more is the breakdown of proteins.

In contrary to protein content, maximum amylose content was obtained in $\mathrm{I}_{12 \mathrm{DAS}}+70 \mathrm{~mm}$ CPE treatment $(23.1$ \%) which was statistically at par with $\mathrm{I}_{12} \mathrm{DAS}+50 \mathrm{~mm} \mathrm{CPE}$ $(22.1 \%), \mathrm{I}_{9 \mathrm{DAS}}+50 \mathrm{~mm} \mathrm{CPE}(21.9 \%), \mathrm{I}_{9 \mathrm{DAS}}+70 \mathrm{~mm} \mathrm{CPE}(22.7$ $\%), \mathrm{I}_{6 \mathrm{DAS}}+50 \mathrm{~mm} \mathrm{CPE}(21.5 \%)$ and $\mathrm{I}_{6 \mathrm{DAS}}+70 \mathrm{~mm} \mathrm{CPE}(22.3$ $\%$ and significantly better than conventional transplanting $(20.3 \%), \mathrm{I}_{6 \mathrm{DAS}}+30 \mathrm{~mm}$ CPE $(20.1 \%)$, I $\mathrm{I}_{9 \mathrm{DAS}+}$ $30 \mathrm{~mm} \mathrm{CPE}(21.0 \%)$ and $\mathrm{I}_{12 \mathrm{DAS}}+30 \mathrm{~mm} \mathrm{CPE}(21.1 \%)$. Amylopectin content was not influenced significantly by any of the irrigation regime during the period of study.

Generally, the starch in rice consists of amylose and amylopectin and the proportion of both varies. Amylose content is important because it has a marked effect on the cooking and palatability characteristics. Amylose content in grain affects the softness and stickiness of cooked rice (Khalid and Chaudhry, 1999). As the water stress in the different irrigation treatments increased, amylose content of grains increased. There is negative correlation of amylose and protein content in the rice grains especially under moisture stress conditions (Fofana et al., 2010). This might be due to the reason that the starch and protein, both are manufactured in grain using sugar as carbon source, thus, moisture content might regulate the synthesis of starch and protein on competition for carbon.

Cooking quality as influenced by irrigation schedules: The maximum value of minimum cooking time in milled rice was found in $\mathrm{I}_{6 \mathrm{DAS}}+30 \mathrm{~mm} \mathrm{CPE}$, which was statistically at par with conventional transplanting and the grains took significantly more minimum cooking time as compared to all other treatments (Table 2). The maximum elongation ratio was obtained in case of conventional transplanting and it showed the same trend as shown by minimum cooking time. Minimum cooking time of milled grains is closely related with the protein content (Singh et al., 2011). It followed the same trend as followed by the protein content. Proteins being harder in nature provide hardness to grain (Leesawatwong et al., 2005), thus harder grains might have taken more time for cooking in a boiling water bath. Stressed samples have lower gelatinization temperature and they gelatinize quicker and moreover, there is a positive correlation between gelatinization temperature and cooking time (Veronic et al., 2007). The higher elongation ratio in the plots receiving more amount of irrigation water might also be attributed to the gelatinization behavior of the carbohydrates among rice grains produced in these plots. The maximum value of gruel solids loss was observed in $\mathrm{I}_{12 \mathrm{DAS}}+70 \mathrm{~mm}$ CPE followed by $\mathrm{I}_{9 \mathrm{DAS}}+70 \mathrm{~mm}$ CPE and significantly better than all the irrigation schedules. There is a highly significant correlation of gruels solid loss with amylose content (Singh et al., 2005). Irrigation schedules failed to cause significant change in the length: breadth of cooked milled rice and water uptake ratio.

\section{Conclusion}

In our study, the yield produced by direct seeded basmati rice where water was withheld for 6 days after sowing and subsequent irrigations were applied at 30 mm CPE (3.50 Mg ha ${ }^{-1}$ ) was statistically at par with conventional transplanting $\left(3.79 \mathrm{Mg} \mathrm{ha}^{-1}\right)$. This direct seeded rice treatment produced the highest values of the milling qualities like brown $(80.3 \%)$, milled (69.9 $\%)$ and head rice recoveries $(51.1 \%)$ as well asprotein content $(7.26 \%)$ among all the direct seeded treatments. Thus, in the light of present study, in Indian Punjab, direct seeded basmati rice can be produced by adopting the irrigation schedule of withholding the first irrigation for 6 days and follow up irrigations at $30 \mathrm{~mm} \mathrm{CPE}$ with comparable yields to conventional puddled transplanted basmati rice without compromising the grain quality.

\section{REFERENCES}

Agarwal, G. C., Sidhu, A. S. and Singh, N. T. (1995). Effect of the interaction of transplanting rate, irrigation schedule and $\mathrm{N}$ on rice yield. IRRN, 14: 22-24

Cagampang, G. B., Cruz, L. J., Espiritu, S. G., Santiago, R. G. and Juliano, B. O. (1966). Studies on the extraction and composition of rice proteins. Cereal Chem., 43:145 $-155$

Carlos, A. C. C., Orivaldo, A., Rogério, P. S. and Gustavo, P. M. (2008). Grain quality of upland rice cultivars in response to cropping systems in the Brazilian tropical savanna. Sci. Agric., (Piracicaba, Braz.), 65(5): 468-473

Chapagain, A. K. and Hoekstra, A.Y. (2011).The blue, green and grey water footprint of rice from production and consumption perspectives. Ecological Economics, 70: 749-758

Chen, J. G. and Zhu, J. (1999). Genetic effects and genotype $\times$ environment interactions for cooking quality traits in Indica $\times$ Japonica crosses of rice (Oryza sativa L.). Euphytica, 109: 9-15

Cheng,W., Zhang, G., Zhao, G., Yao, H. and Xu, H. (2003). Variation in rice quality of different cultivars and grain positions as affected by water management. Field 
Crops Res., 80: 245-252

Cochran, W. G. and Cox, G. M. (1967). Experimental Designs. John Wiley Publisher's. New York.

Fofana, M., Cherif, M., Kone, B., Futakuchi, K. and Audebert, A. (2010). Effect of water deficit at grain repining stage on rice grain quality. $J$ Agric Biotec \& Sustain. Develop., 2: 100-107

Huang, D. F., Xi, L. L., Wang, Z. Q., Liu, L. J. and Yang, J. C. (2008). Effects of irrigation regimes during grain filling on grain quality and the concentration and distribution of cadmium in different organs of rice. Acta Agronomica Sinica, 34: 456-464

Khalid, M. and Chaudhry, A. U. (1999). Impact of nitrogen levels and its application methods on yield and kernel quality of fine rice. Pak.J.Agri. Sci., 36: 25-26

Kumar, V. and Ladha, J. K. (2011). Direct seeding of rice: recent developments and future research needs. $A d v$. Agron., 111: 297-413

Leesawatwong, M., Jamjod, S., Kuo, J., Dell, B. and Rerkasem, B. (2005). Nitrogen fertilizer increases seed protein and milling quality of rice. Cereal Chem., 82: 588-593

Low, N. H. (1994). Carbohydrate analysis. In: Nielsen S S (ed)Introduction to the chemical analysis of foods. Jones and Barlett publishers, London ,U K, p142

Mahajan,G., Chauhan, B. S. and Gill, M. S. (2011). Optimal nitrogen fertilization timing and rate in dry - seeded rice in northwest India. Agron J., 103: 1676-1682

Mahajan, G., Timsina, J., Jhanji, S., Sekhon, N. K. and Singh, K. (2012).Cultivar response, dry-matter partitioning and nitrogen-use efficiency in dry directseeded rice in Northwest India. J. Crop Improvement, 26:767-790

Michael, D., Pierre, Y. and Ves, L. G. (1996). Effect of drainage date on yield and dry matter partitioning in irrigated rice. Field Crops Res., 46: 117-126

Pandey, A., Kumar, A., Pandey, D. S. and Thongbam, P. D. (2014). Rice quality under water stress. Indian J. $A d v$. Plant Res., 1(2): 23-26

Sandhu, S. S., Mahal, S. S. and Kaur, A. (2014). Quality and productivity of rice as influenced by planting methods, nitrogen levels and irrigation scheduling in Northwest India. Oryza, 51(4): 290-297

Shekara, B. G., Sharnappa and Krishnamurthy, N. (2010). Effect of irrigation schedules on growth and yield of aerobic rice (Oryza sativa L.) under varied levels of farmyard manure in Cauvery command area. Indian $J$. Agron., 55: 35-39

Singh, A. K. (2004). Enhancing water use efficiency in rice. In: International Symposium on rice: From Green revolution to Gene revolution. Exended Summaries,Pp. 13. 4-6, October 2004, DRR, Rajendra nagar, Hyderabad, India.

Singh, N., Kaur, L., Sodhi, N. S., and Sekhon, K. S. (2005). Physicochemical, cooking and textural properties of milled rice from different Indian rice cultivars. Food Chem., 89: 253-259

Singh, N., Pal, N., Mahajan, G., Singh, S., and Shevkani, K. (2011). Rice grain and starch properties: Effects of nitrogen fertilizer application. Carb. Polymers, 86: 219225

Tuong, T. P. and Bouman, B. A. M. (2003). Rice production in waterscarce environments. Proceedings of Water Production Workshop, Pp 53-67. 12-14 November 2001, International Water Management Institute, Colombo, Sri Lanka.

Veronic, V., Brigitte, P., Judith, B., Stephan, H., Xavier, R. and Christian, M. (2007). Cooking behavior of rice in relation to kernel physicochemical properties. J. Agric. Food Chem., 55: 336-346

Xie, G., Yang, J., Wang, Z., and Zhi, Q. (2001). Grain filling characteristics of rice and their relationship to physiological activities of grains. Acta Agronomica Sinica, 27: $557-565$

Yang, J., Zhang, J., Wang, Z., Zhu, Q., and Wang, Q., (2001). Remobilization of carbon reserve in response to water deficit during grain filling of rice. Field Crops Res., 71: 47-55

Zhang, X., Shi, C., Hisamitsu, H., Katsura, T., Bao, G., Feng, S. and Ye, S. (2002). The difference in grain amylose content different panicle parts of Japonica rice variety. Acta Agronomica Sinica, 28: 99- 103 